\title{
A Direct Comparison of Biological Response Modulation and Clinical Side Effects by Interferon-Betaser, Interferon-Gamma, or the Combination of Interferons Beta ser $_{\text {and Gamma in Humans }}$
}

Joan H. Schiller, Barry Storer, Donna M. Paulnock, Raymond R. Brown, Surinder P. Datta, Patricia L. Witt, and Ernest C. Borden Departments of Human Oncology, Medical Microbiology, Medicine, and Statistics, University of Wisconsin Clinical Cancer Center, Madison, Wisconsin 53792; and William S. Middleton Veterans Administration Hospital, Madison, Wisconsin 53705

\begin{abstract}
To directly compare clinical side effects and biological response modification, IFN- $\beta_{\text {ser }}$, IFN- $\gamma$, or the combination of IFN- $\beta_{\text {ser }}$ plus IFN- $\boldsymbol{\gamma}$ was administered to 21 cancer patients. Each IFN or the combination was given intravenously on days 1,8 , and 15 in varied order. Each IFN and the combination resulted in significant $(P<0.05)$ modulation of IFN-induced proteins. IFN- $\beta_{\text {ser }}$ was more effective than IFN- $\gamma$ in enhancing 2-5A synthetase activity $(P=0.001)$. IFN- $\gamma$ was more effective than IFN- $\beta_{\text {ser }}$ in enhancing serum $\beta_{2}$ microglobulin expression $(P=0.05)$ and indoleamine dioxygenase activity, as assessed by decreased serum tryptophan $(P=0.03)$. The combination enhanced tryptophan catabolism more effectively than IFN- $\beta_{\text {ser }}$ in a dose-dependent manner $(P<0.03)$. IFN- $\beta_{\text {ser }} /$ IFN- $\gamma$ did not potentiate natural killer cells or antibody-dependent cellular toxicity (ADCC). IFN- $\beta_{\text {ser }} /$ IFN- $\boldsymbol{\gamma}$ enhanced monocyte guanylate cyclase activity, as assessed by serum neopterin, more effectively than IFN- $\gamma$ alone $(P=0.005)$. Both IFNs and the combination resulted in increases in HLA class II expression on monocytes. However, no significant difference in the level of induction of HLA DQ and HLA DR expression between IFN- $\beta_{\text {ser }} /$ IFN- $\boldsymbol{\gamma}$ and either IFN- $\beta_{\text {ser }}$ or IFN- $\boldsymbol{\gamma}$ was noted. Although frequency and servity of side effects of IFN- $\beta_{\text {ser }}$ IFN- $\gamma$, or the combination were dose related, induction of induced proteins (with exception of influences on tryptophan catabolism) were not a function of dose administered over the 10-fold range. Continued treatment with the combination intravenously three times a week for 4 wk sustained but did not further potentiate, most of the changes in interferoninduced proteins. Thus, IFN- $\beta_{\text {ser }}$ and IFN- $\gamma$ each resulted in effective and essentially equivalent patterns of induction of induced proteins. When combined, however, these IFNs did not result in potentiation of biological response modification in vivo. (J. Clin. Invest. 1990. 86:1211-1221.) Key words: clinical cancer trial $\bullet$ interferon $\bullet$ biological response modification
\end{abstract}

\section{Introduction}

IFNs are prototype lymphokines with a broad range of antiviral, immunomodulatory, and antiproliferative effects. Three major classes (IFNs alpha, beta, and gamma) have been defined based on differences in amino acid structure. Biologic

Address reprint requests to Dr. Joan H. Schiller, University of Wisconsin, Clinical Cancer Center, Rom K4/666, 600 Highland Ave., Madison, WI 53792.

Received for publication 15 December 1989 and in revised form 25 April 1990.

The Journal of Clinical Investigation, Inc.

Volume 86, October 1990, 1211-1221 differences between the three groups also exist that may have therapeutic implications. IFN- $\beta$ has been shown to have more antiproliferative activity in vitro against many solid tumors than IFN- $\alpha$ (1). IFN- $\gamma$ has unique immunomodulatory properties, including macrophage activation (2) and differentiating activity (3), and was more potent in augmenting Fc receptor expression (4) and HLA class II antigen expression on tumor cells (5), than IFN- $\alpha$ or IFN- $\beta$.

Clinically, IFN- $\alpha$ has well-defined activity against a variety of neoplasms and is currently undergoing evaluation in phase III trials (6). Combinations of IFN- $\alpha$ or IFN- $\beta_{\text {ser }}$ and IFN- $\gamma$ are of clinical interest because of synergistic antiproliferative effects in a variety of tumor types in both in vitro and murine model systems (7-9). Recent clinical trials of combinations of IFN- $\beta$ or IFN- $\alpha$ with IFN- $\gamma(10,11)$ have raised the question as to how a combination of IFNs will be tolerated when compared with either IFN alone. Furthermore, results from a phase I trial of IFN- $\alpha$ and IFN- $\gamma$ suggest that this combination may not be tolerable when administered over long periods of time (11).

We conducted a phase I trial of IFN- $\beta_{\text {ser }}$ IFN- $\gamma$, and the combination (IFN- $\beta_{\text {ser }} /$ IFN- $\gamma$ ) that was designed to directly compare in the same patient these three alternatives. Specific clinical objectives were to compare side effects and organ toxicities associated with three different IFN treatments, determine whether the combined administration of IFN- $\beta_{\text {ser }} /$ IFN- $\gamma$ would result in increased toxicity as compared with either IFN alone, and determine whether a 10-fold increase in IFN dose would result in enhanced toxicity. To compare modulation of host responses, IFN-induced proteins (HLA class I and class II expression, 2-5A synthetase, and indoleamine 2-3 dioxygenase) and effector cell function natural killer $(\mathrm{NK})^{1}$ cell cytotoxicity, antibody-dependent cellular toxicity (ADCC), and monocyte activation) were assessed. These parameters were chosen for study because they represent host responses that were known to be modulated by IFN- $\beta_{\text {ser }}$ and IFN- $\gamma$ both in vitro and in vivo. The purpose of these assessments was to determine $(a)$ the effect of both single administration and the combination on biological responses, $(b)$ which of two dose levels of combined IFN- $\beta_{\text {ser }} /$ IFN- $\gamma$, differing by 10 -fold, would produce the greatest augmentation of these biological responses, and $(c)$ whether the combined administration of IFN- $\beta_{\text {ser }} /$ IFN- $\gamma$ would result in sustained increases in biological responses over 4 wk.

\section{Materials and Methods}

IFNs. IFN- $\beta_{\text {ser }}$ (specific antiviral activity $1-2 \times 10^{8}$ units $/ \mathrm{mg}$ of protein; Triton Biosciences, Inc.) and IFN- $\gamma$ (specific antiviral activity

1. Abbreviations used in this paper: $\mathrm{ADCC}$, antibody-dependent cellular toxicity; MFI, mean fluorescence intensity; NK, natural killer. 
1.3-3.3 $\times 10^{7}$ units/mg of protein; Biogen, Cambridge, MA) (12) were provided through the Biological Response Modifiers Program, National Institutes of Health (Frederick, MD). IFN- $\beta_{\text {ser }}$ is a synthetic mutant protein with a substitution of serine for cysteine at amino acid position 17 (13).

Patient selection. This study was open to patients with histologically confirmed malignancies for which no standard therapy was known to be effective. Eligibility criteria included an Eastern Cooperative Oncology Group performance status of 0 or 1 and adequate hematologic, hepatic, and renal function. Patients could have received no more than two prior cytotoxic chemotherapy regimens and could not have received cytotoxic chemotherapy for at least $3 \mathrm{wk}$ before initiation of IFN ( $6 \mathrm{wk}$ for mitomycin C or nitrosoureas); radiation therapy, hormones, glucocorticosteroids, for at least $2 \mathrm{wk}$; or IFN- $\alpha$ or other immunotherapy for at least $4 \mathrm{wk}$. Patients with clinically significant heart disease, CNS involvement, or prior treatment with IFN- $\beta_{\text {ser }}$ or IFN- $\gamma$ were excluded. While on study, patients were not allowed barbiturates, aspirin, corticosteroids, or nonsteroidal antiinflammatory drugs. All patients gave informed consent.

21 patients with a variety of tumor types were entered on study (Table I). One patient at the higher dose level discontinued therapy within the first $3 \mathrm{wk}$ due to personal reasons and was not evaluated for response.

Study design. Two dose levels were studied (Table II). The low-dose level A consisted of $3 \times 10^{6}$ IU of IFN- $\beta_{\text {ser }}$ and $200 \mu \mathrm{g}$ of IFN- $\gamma(1,000$ $\left.\mu \mathrm{g} \approx 15 \times 10^{6} \mathrm{IU}\right)$. This dose level represented one-tenth the dose of the high-dose level B $\left(30 \times 10^{6}\right.$ IU of IFN- $\beta_{\text {ser }}$ and $2,000 \mu \mathrm{g}$ of IFN- $\left.\gamma\right)$, which was the maximum tolerated dose determined from a previous phase I trial (10). For all combined treatments, IFN- $\gamma$ was given first intravenously over $10 \mathrm{~min}$ followed by a 10 -min injection of IFN- $\beta_{\text {ser }}$. Clinical parameters were evaluated before and $24 \mathrm{~h}$ after the day 1,8 , and 15 treatment. Each injection was followed by a 1-wk washout period. Clinical parameters, biological response and disease response were assessed again after $4 \mathrm{wk}$ of maintenance therapy. The order of administration of IFN- $\beta_{\text {ser }}$, IFN- $\gamma$, and IFN- $\beta_{\text {ser }} /$ IFN- $\gamma$ on days 1,8 , and 15 was distributed equally among patients in each dose level to control for cumulative dose effects.

Table I. Patient Characteristics

\begin{tabular}{lcc}
\hline & Low dose & High dose \\
\hline Age range & $39-70$ & $26-69$ \\
Median & 57 & 52 \\
Sex & & \\
$\quad$ Male & 4 & 5 \\
$\quad$ Female & 6 & 6 \\
Prior treatment & & \\
$\quad$ None & 4 & 1 \\
Chemotherapy & 5 & 4 \\
Radiation therapy & 1 & 7 \\
Immunotherapy & 4 & 1 \\
$\quad$ Hyperthermia or hormonal therapy & 0 & 2 \\
Performance status: & & \\
$\quad 0$ & 5 & 1 \\
$\quad$ Tumor & 5 & 10 \\
$\quad$ Lung & & \\
Melanoma & 2 & 2 \\
Renal & 1 & 1 \\
$\quad$ Other* & 1 & 3 \\
Total number & 6 & 5 \\
\cline { 2 - 2 }
\end{tabular}

* Breast, colorectal, pancreas, chordoma, adenocarcinoma of unknown primary.
IFN doses were modified for grade 3 or 4 toxicities. Grade 3 symptomatology was defined as symptoms that required medication for relief, did not resolve with repeated IFN treatments, resulted in 5-10\% weight loss from baseline, or resulted in a drop in performance status to ECOG level 3. Grade 4 symptomatology included symptoms that were inadequately relieved by medication, caused a $>10 \%$ weight loss, or a drop in performance status to level 4.

IFN treatments were withheld for any grade 3 or 4 toxicity until the parameter returned to less than a grade 3 toxicity. Therapy was then resumed with the dose of each IFN reduced by one dose level or to $50 \%$ of dose level $\mathrm{A}$

IFN pharmacokinetics. Serum samples were obtained immediately before initiation of the IFN infusion and at $15 \mathrm{~min}, 1,2,4,6$, and $24 \mathrm{~h}$ thereafter.

Because an ELISA assay specific for IFN- $\beta_{\text {ser }}$ was not available, total serum antiviral activity was assayed (by Cetus Corp., Emeryville, CA) in a cytopathic effect assay (CPE) that uses human fibroblast GM2504E cells and VSV as the challenge virus. An internal laboratory standard calibrated against an international reference preparation of human fibroblast IFN (G023-902-527) was included in each assay. Titers were reported in international units/milliliter and are the mean of three titration results. Because IFN- $\beta$ and IFN- $\gamma$ do not show equal activity on a per unit basis in the assay, total antiviral activity as measured here should not be interpreted as the sum of the actual IFN- $\beta$ and IFN- $\gamma$ titers. Serum IFN- $\gamma$ levels were determined (by Biogen, Inc.) with a modified double-antibody sandwich ELISA. An internal laboratory standard was used to generate a standard curve, which had been calibrated against an international standard for antiviral potency, G023-901-530, to give values expressed in international units/milliliter. Values represent the mean of four titration results.

$2-5 A$ synthetase and serum $\beta_{2}$ microglobulin. The $2-5 \mathrm{~A}$ oligoadenylate synthetase assay was performed as previously described on peripheral blood lymphocytes (14). A commercially available radioimmune assay kit (Pharmacia Fine Chemicals, Piscataway, NJ) was used for the quantitative determination of serum $\beta_{2}$ microglobulin levels.

Monocyte surface antigen expression. Determination of monocyte surface antigen expression was performed as previously described (15). Both the percentage of positive cells and the mean channel of fluorescence intensity (MFI) of positive cells were determined in each analyses. Cells corresponding to the monocyte population were identified on the basis of characteristic forward angle and $90^{\circ}$ (right angle) light scatter profile (16). In some experiments, the monocyte population identified by light scatter properties was confirmed by staining with anti-Leu-M3 antibody. In all cases where these two methods were compared, identical results were obtained whether the identification of monocytes was done by light scatter profile analysis or on the basis of Leu-M3 staining results (data not shown).

$N K$ and $A D C C$ cell cytotoxicity. Peripheral mononuclear cells were separated from whole blood by centrifugation over a Ficoll hypaque gradient. NK cell activity was assessed in a 4- ${ }^{51} \mathrm{Cr}$-release assays using K562 target cells (17), and ADCC activity was assessed using ${ }^{51} \mathrm{Cr}$ labelled Chang cells. ADCC was assessed by adding either medium or rabbit anti-Chang cell antiserum (final dilution $=10^{-2}$ ) to appropriate cultures. NK and ADCC cell activity was determined in quadruplicate at six effector-target ratios (3.125:1, 6.25:1, 12.5:5, 25:1, 50:1, and 100:1). Lytic units (LU) were calculated using a modification of the exponential fit equation. One LU was defined as the number of lymphocytes required to result in $30 \%$ specific ${ }^{51} \mathrm{Cr}$ release.

Serum neopterin levels. Serum neopterin was assayed by a commercially available RIA kit (Neopterin-RIAcid; Henning Berlin $\mathrm{GmbH}$, distributed by DRG International, Inc., Mountainside, NJ). Samples were counted in a 10-well gamma counter (Isodata, Inc., Palatine, IL). A simultaneously prepared standard curve was used to calculate neopterin levels in the test samples.

Urinary kynurenine and serum tryptophan levels. 24-h urine collections, preserved by addition of thymol, were made before, and 24 and $48 \mathrm{~h}$ after IFN administration. Kynurenine was measured by an alkaline steam-volatile amine method previously described from this laboratory (18). Appropriate standard curves and recoveries were used 


\begin{tabular}{|c|c|c|c|c|c|c|}
\hline & \multicolumn{2}{|c|}{ Dose levels } & \multirow[b]{2}{*}{ Day 1} & \multirow[b]{2}{*}{ Day 8} & \multirow[b]{2}{*}{ Day 15} & \multirow[b]{2}{*}{ Maintenance therapy } \\
\hline & A & B & & & & \\
\hline IFN- $\beta_{\text {ser }}$ & $3 \times 10^{6}$ units & $30 \times 10^{6}$ units & & & & \\
\hline \multirow[t]{5}{*}{ IFN- $\gamma$} & $200 \mu \mathrm{g}$ & $2,000 \mu \mathrm{g}$ & & & & \\
\hline & \multicolumn{2}{|c|}{ No. of patients } & & & & \\
\hline & 4 & 4 & IFN- $\beta_{\text {ser }}$ & IFN- $\gamma$ & IFN- $\beta_{\text {ser }} / \mathrm{IFN}-\gamma$ & $\begin{array}{l}\text { IFN- } \beta_{\text {ser }} / \mathrm{IFN}-\gamma \\
\text { three times } / \text { wk }\end{array}$ \\
\hline & 3 & 3 & IFN- $\gamma$ & IFN- $\beta_{\text {ser }} / \mathrm{IFN}-\gamma$ & IFN- $\beta_{\text {ser }}$ & $\begin{array}{l}\text { IFN- } \beta_{\text {ser }} / \mathrm{IFN}-\gamma \\
\text { three time } / \text { wk }\end{array}$ \\
\hline & 3 & 4 & IFN- $\beta_{\text {ser }} /$ IFN- $\gamma$ & IFN- $\beta_{\text {ser }}$ & IFN- $\gamma$ & $\begin{array}{l}\text { IFN- } \beta_{\text {ser }} / \text { IFN- } \gamma \\
\text { three times } / w k\end{array}$ \\
\hline Total & 10 & 11 & & & & \\
\hline Biological Response Assessment & & & Day 1,2 & Day 8,9 & Day 15,16 & $\begin{array}{l}\text { After } 4 \text { wk of maintenance } \\
\text { therapy }\end{array}$ \\
\hline
\end{tabular}

for quantitation results. The method is sensitive and specific with no interference from commonly used medications.

Blood serum samples for tryptophan levels were obtained before treatment, and at 4,8 , and $24 \mathrm{~h}$ after IFN administration. Serum or plasma tryptophan levels were measured by a fluorometric method adapted to the Technicon Autoanalyzer (Technicon Instruments, Tarrytown, NY) (19).

Statistical analysis. Paired $t$ tests were used to test the null hypothesis that mean treatment effects were zero, both within each dose level and for both dose levels combined, for each interferon used alone and for the combination. Necessarily, this analysis was restricted to patients for whom both pre- and posttreatment determinations were made for a particular IFN type. The trial was balanced with respect to the sequencing of IFNs. Approximately equal numbers of patients received each IFN as the first, second, or third injections.

Paired $t$ tests were also used to test the null hypothesis that mean differences between effects of beta and gamma interferon, and between single-agent and combination treatment, were zero. This paired analysis used only patients for whom pre- and posttreatment measurements were available for both interferons/combination in question. The comparisons were made within each dose level and for both dose levels combined.

Two-sample $t$ tests were used to test the null hypothesis that the mean difference between treatment effects at the two different dose levels were zero for each interferon used alone and for the combination. We also assessed influence of injection sequence on clinical and biological endpoints; no significant differences occurred. Although absence of such an association does not prove lack of interaction, we feel these effects, if any, were relatively minor.

Analysis of all biological response parameters was based on $\log$ transformed data. This is equivalent to analysis of a log stimulation index, where stimulation index is defined as the ratio of the posttreatment to pretreatment values. For purposes of presentation in text and figures, mean treatment effects have been reexpressed as percent changes or fold increases.

The pre- and posttreatment means from the raw data are indicated in the figure legends. Because the figures are based upon reexpression of log transformed data, these may not correspond exactly.

\section{Results}

\section{IFN-induced proteins}

$H L A-D R$ expression on monocytes. $24 \mathrm{~h}$ after the administration of IFN- $\beta_{\text {ser }}$, IFN- $\gamma$, or the combination, there was a signif- icant increase in the mean percentage of cells positive for HLA-DR (Fig. $1 A$ ). Although in a few patients the percentage of monocytes positive for HLA-DR expression decreased after IFNs (Fig. $2 \mathrm{~A}$ ), overall, the mean percentage of cells positive for HLA-DR increased from 65.8 to $81.9 \% 24 \mathrm{~h}$ after treatment with IFN- $\beta_{\text {ser }}$, from $71.5 \%$ to $78.7 \% 24 \mathrm{~h}$ after treatment with IFN- $\gamma$, and from 69.9 to $81.8 \% 24$ hours after IFN- $\beta_{\text {ser }} /$ IFN- $\gamma$ treatment $(P=0.011,0.019$, and $<0.001$, respectively). The percentage of cells positive for HLA-DR increased in 15 of 19 patients receiving IFN- $\beta_{\text {ser }}, 16$ of 19 receiving IFN- $\gamma$, and 18 of 21 receiving the combination. The level of antigen expression (MFI) for cells positive for HLA-DR in the three treatment groups increased 37,50 , and $47 \%$, respectively $(P$ $=0.003,<0.001$, and $<0.001$, respectively). The MFI for cells positive for HLA-DR increased in 15 of 19 patients receiving IFN- $\beta_{\text {ser }}, 17$ of 19 receiving IFN- $\gamma$, and 21 of 21 receiving the combination. Although these changes were not correlated with monocyte counts, we have previously shown that fluctuations in absolute numbers of monocytes did not correlate with changes in class II antigen expression in patients treated with IFN- $\beta$ or IFN- $\gamma(15)$.

The data were analyzed to determine whether the combination of IFN- $\beta_{\text {ser }} /$ IFN- $\gamma$ significantly increased HLA-DR expression more than IFN- $\beta_{\text {ser }}$ or IFN- $\gamma$. A similar fraction of patients had an increase in positive monocytes after all treatments (Fig. 2, $A$ and $B$ ). The combination of IFN- $\beta_{\text {ser }}$ and IFN- $\gamma$ was not significantly different from either IFN alone in its effect on the MFI or percentage of cells positive for HLADR $(P \geq 0.25)$. Similarly, there was no significant difference between IFN- $\beta_{\text {ser }}$ and IFN- $\gamma$ in their effect on the MFI or percentage of cells positive for HLA-DR $(P \geq 0.08)$. No significant $(P \geq 0.1)$ dose response relationship was observed for any of the three treatment groups (Fig. 2, $A$ and $B$ ).

After 4 wk of treatment with IFN- $\beta_{\text {ser }} /$ IFN- $\gamma$, the percentage of cells positive for HLA-DR and the MFI of those cells remained significantly higher than pretreatment values $(P$ $=0.002$ and 0.04 , respectively) (Fig. $1 C$ ).

$H L A-D Q$ expression on monocytes. Significant increases were also seen in the mean percentage of monocytes positive for HLA-DQ after IFN- $\beta_{\text {ser }}$, IFN- $\gamma$, and the combination (Fig. $1 B)(P=0.02,<0.001,0.001$, respectively $)$. The percentage of 
A

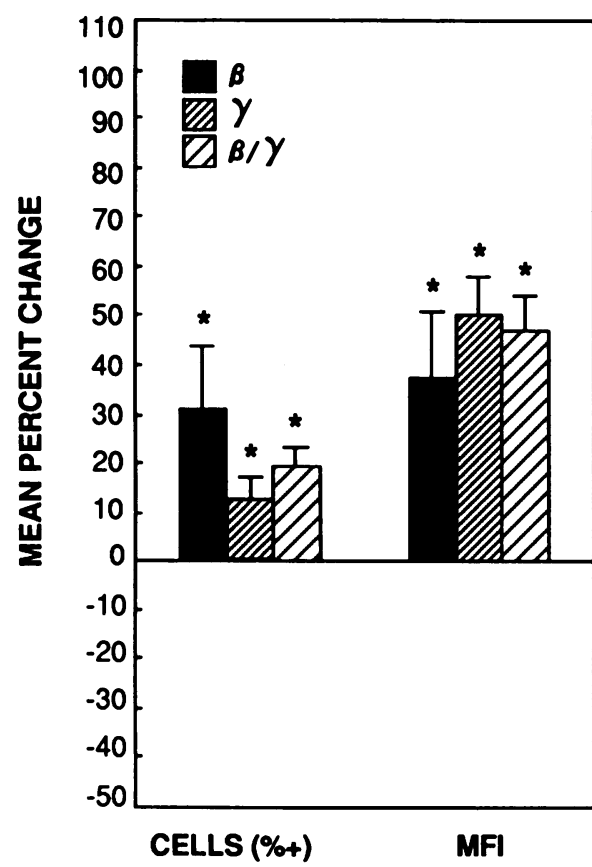

B

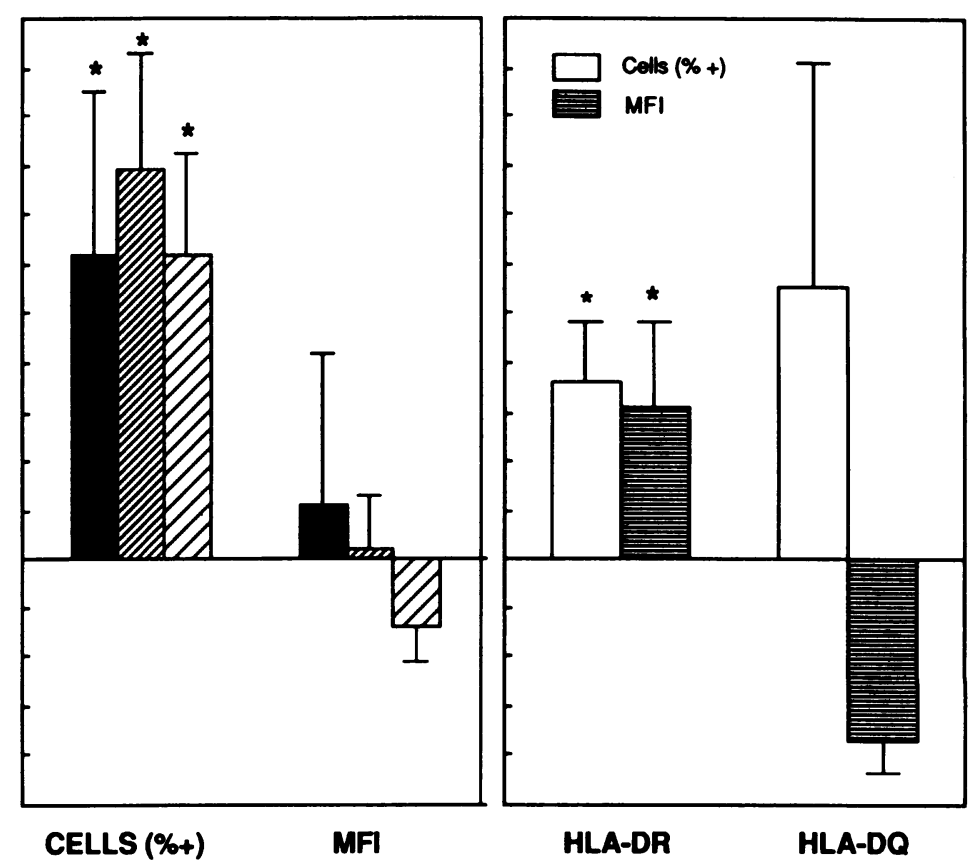

Figure 1. Effects of combined dose levels of IFN- $\beta_{\text {ser }}(\beta)$, IFN- $\gamma(\gamma)$, and IFN- $\beta_{\text {ser }} /$ IFN- $\gamma(\beta / \gamma)$ on $(A)$ HLA-DR and $(B)$ HLA-DQ expression on monocytes. (Percentage of cells positive and MFI.) Results are given as the mean percent change (reexpressed from analysis of log transformed data) of values measured: $24 \mathrm{~h}$ posttreatment compared with values measured before treatment; and $(C)$ after 4 wk of maintenance therapy with IFN- $\beta_{\text {ser }} /$ IFN- $\gamma$. The mean percentage of cells positive for HLA-DR and DQ increased from 65.8 to $81.9 \%$ and from 9.0 to $17.3 \% 24 \mathrm{~h}$ after IFN- $\beta_{\text {ser }}$, from 71.5 to $79.4 \%$ and from 10.1 to $21.7 \%$ after IFN- $\gamma$, and from 69.9 to $81.8 \%$ and from 9.5 to $16.6 \%$ after the combination, respectively. The MFI on monocytes positive for HLA-DR and DQ increased from 43.0 to 56.6 and from 17.9 to $18.524 \mathrm{~h}$ after IFN- $\beta_{\text {ser }}$, from 44.5 to 67.9 and from 18.2 to 19.3 after IFN- $\gamma$, and 46.8 to 68.6 and from 17.4 to 15.6 after the combination, respectively. After 4 wk of maintenance therapy with IFN- $\beta_{\text {ser }}$ and IFN- $\gamma$, the mean percentage of cells positive for HLA-DR and DQ increased from 64.8 to $85.7 \%$ and 9.4 to $15.9 \%$, respectively. The MFI for HLA-DR increased from 47.8 to 70.7, and HLA-DQ decreased from 19.4 to 12.0. Asterisks indicate signifcant differences compared with baseline with $P<0.05$. Error bars $=\mathrm{SE}$.

monocytes positive for HLA-DQ increased in 14 of 19 patients receiving IFN- $\beta_{\text {ser }}, 15$ of 19 patients receiving IFN- $\gamma$, and 16 of 21 receiving the combination. In contrast to HLA-DR expression, no significant changes in the MFI of those cells positive for HLA-DQ were observed after treatment with IFN- $\beta_{\text {ser }}$, IFN- $\gamma$, and IFN- $\beta_{\text {ser }} /$ IFN- $\gamma(P=0.68,0.86$, and 0.09 , respectively) (Fig. $1 B$ ). The MFI of cells positive for HLA-DQ increased in 7 of 19 patients receiving IFN- $\beta_{\text {ser }}, 7$ of 19 receiving IFN- $\gamma$, and 17 of 21 receiving the combination. Similar to the results seen with HLA-DR, the combination of IFN- $\beta_{\text {ser }}$ and IFN- $\gamma$ was not significantly different from either IFN alone in its effect on the MFI or percentage of cells positive for HLADQ $(P \geq 0.25)$. IFN- $\beta_{\text {ser }}$ did not differ significantly from IFN- $\gamma$ in its ability to enhance the number of monocytes expressing HLA-DQ $(P=0.93)$.

The data was also analyzed to determine if there was a significant dose response in any of the three IFN treatment groups. IFN- $\beta_{\text {ser }}$ at $30 \times 10^{6}$ units was significantly more effective in enhancing the percentage of cells positive for HLA-DQ than $3 \times 10^{6}$ units $(P=0.04)$. The higher dose level of IFN- $\beta_{\text {ser }} /$ IFN- $\gamma$ decreased the MFI of cells positive for HLA$\mathrm{DQ}$ to a greater extent than the lower dose level $(P=0.03)$. No significant dose-response relationship was observed for IFN- $\gamma$ $(P \geq 0.18)$.

After 4 wk of treatment with either of the two dose levels of
IFN- $\beta_{\text {ser }} /$ IFN- $\gamma$, the MFI of DQ positive cells was significantly lower than pretreatment values $(P=0.007)$ (Fig. 1). The percentage of cells positive for HLA-DQ, however, did not remain elevated $(P=0.11)$.

$\beta_{2}$ microglobulin expression on monocytes. The expression of $\beta_{2}$ microglobulin on monocytes was measured and used to assess of HLA Class I expression on specific cell types. There was no significant change in the percentage of cells positive for $\beta_{2}$ microglobulin $24 \mathrm{~h}$ after IFN- $\beta_{\text {ser }}$, IFN- $\gamma$, or IFN- $\beta_{\text {ser }} /$ IFN- $\gamma$ $(P<0.43$ for all three treatment groups) (data not shown). Most monocytes (98\%, data not shown) however, were positive for this antigen before treatment making it difficult to detect further increases in the number of positive cells. However, there was a significant increase in the MFI $(P=0.011$, 0.010 , and 0.001 , respectively) of positive cells (Fig. $3 A$ ). The MFI of monocytes positive for $\beta_{2}$ microglobulin increased in 16 of 20 patients receiving IFN- $\beta_{\text {ser }}, 16$ of 20 patients receiving IFN- $\gamma$, and 16 of 21 patients receiving the combination. There were no significant differences in the level of MFI enhancement between any of the IFN treatments $(P \geq 0.32)$, or between dose levels $(P>0.22)$. After 4 wk of treatment with either of the two IFN- $\beta_{\text {ser }} /$ IFN- $\gamma$ dose levels, the increase in $\beta_{2}$ microglobulin on monocytes compared to pretreatment values, was maintained, although it was no longer statistically significant $(P \geq 0.08)$. 

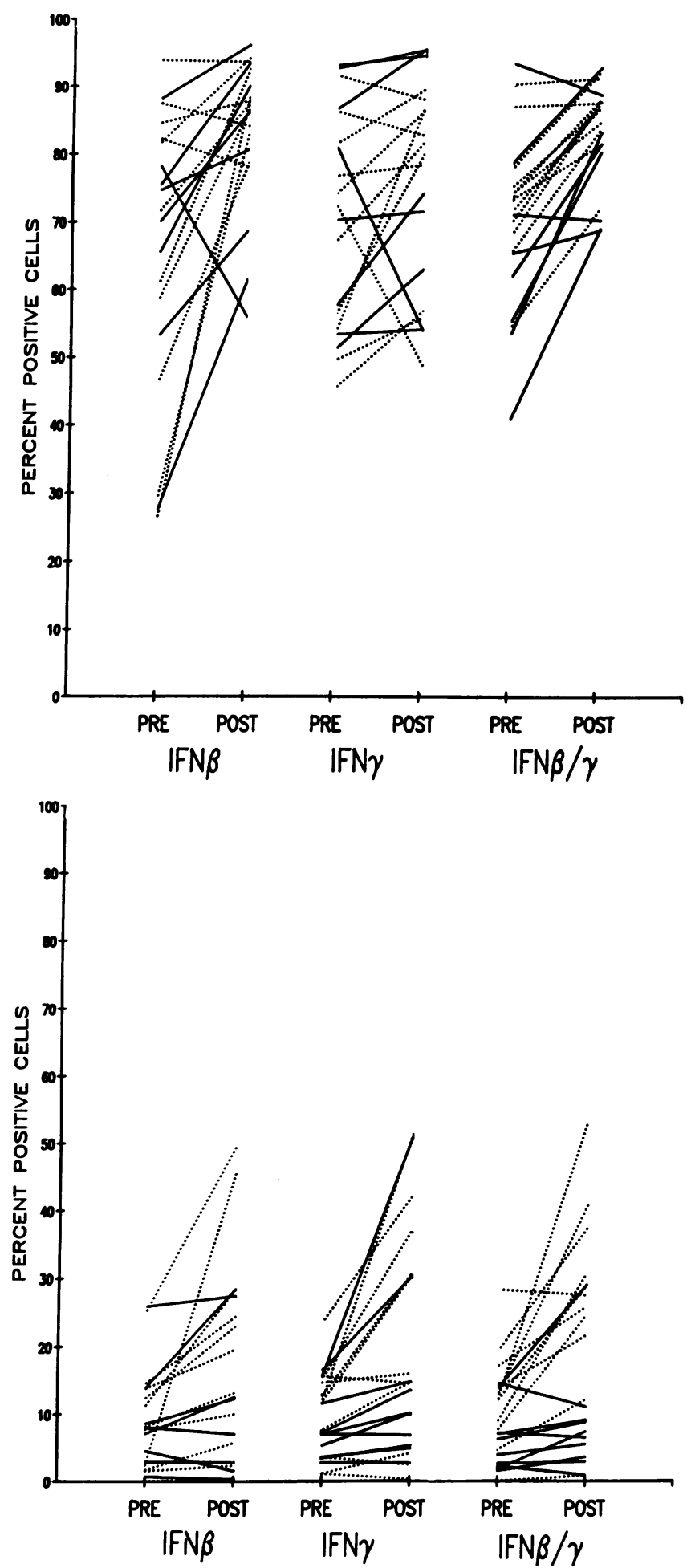

Figure 2. Percentage of monocytes positive for A) HLA-DR and B) HLA-DQ before (pre) and $24 \mathrm{~h}$ after (post) IFN. Each line represents a sample from an individual patient (-) lower dose; (-.--) 10X higher dose.

Serum $\beta_{2}$ microglobulin. Significant elevations in serum $\beta_{2}$ microglobulin were observed $24 \mathrm{~h}$ after treatment with all three IFN(s) $(P<0.001)$ (Fig. $3 B)$. All 21 patients receiving IFN- $\beta_{\text {ser }}$ and the combination had an increase in their serum $\beta_{2}$ microglobulin; 18 of 19 patients receiving IFN- $\gamma$ had an increase. IFN- $\beta_{\text {ser }}$ increased serum $\beta_{2}$ microglobulin 1.29-fold, which was significantly less than the 1.5 -fold increase observed after IFN- $\gamma$, and the 1.63-fold increase observed after IFN- $\beta_{\text {ser }} /$ IFN- $\gamma(P=0.05$ and 0.001 , respectively $)$. The difference between IFN- $\gamma$ and the combination was not statistically significant $(P=0.08)$. Elevations in serum $\beta_{2}$ microglobulin were maintained after $4 \mathrm{wk}$ of treatment at either dose level $(P$ $<0.001$ ) (Fig. 3 B). A significant dose response relationship was observed with either IFN- $\gamma$ or IFN- $\beta_{\text {ser }} /$ IFN- $\gamma$, but not IFN- $\beta_{\text {ser }}(P=0.04,0.01$, and 0.38 , respectively).

$2-5 A$ synthetase activity. IFN- $\beta_{\text {ser }}$ increased serum $2-5 \mathrm{~A}$ synthetase by a mean of 3.2 -fold and in 17 of 20 patients $(P$ $<0.001$ ) (Fig. 4). Similarly, IFN- $\beta_{\text {ser }} /$ IFN- $\gamma$ increased $2-5 \mathrm{~A}$ synthetase activity 2.3 times $(P=0.004)$ and in 15 of 17 patients assessed. IFN- $\gamma$ had no significant effect on 2-5A synthetase activity, increasing it in 7 of 18 patients $(P=0.65)$. The difference in $2-5 \mathrm{~A}$ synthetase enhancement between IFN- $\beta_{\text {ser }}$ and the combination was not statistically significant $(P=$ 0.23 ), although both enhanced 2-5A synthetase more than IFN- $\gamma(P \leq 0.02)$. No significant dose-response relationship was observed for any of the three treatment arms $(P \geq 0.38)$ (Fig. $4 A$ ). The combination IFN- $\beta_{\text {ser }} /$ IFN- $\gamma$ maintained $2-5 \mathrm{~A}$ synthetase activity when administered for 4 wk $(P<0.001)$ (Fig. 4 B).

Indoleamine 2,3 dioxygenase activity as measured by reduction in serum tryptophan levels. At the lower dose, the combination of IFN- $\beta_{\text {ser }} /$ IFN- $\gamma$ produced significant decreases $(P$ $\leq .01$ ) in serum tryptophan levels at 6 and $24 \mathrm{~h}$ (Fig. $5 \mathrm{~A}$ ). Except for IFN- $\beta_{\text {ser }}$ at $6 \mathrm{~h}$, the individual interferons at dose level A did not produce significant changes in tryptophan levels. At the higher dose, IFN- $\gamma$ and the combination caused significant $(P<0.04)$ decreases in tryptophan at all times studied (Fig. $5 \mathrm{~B}$ ), decreasing it in 11 of 11 patients, and 10 of 11 patients, respectively.

There was no significant difference between effects of IFN- $\gamma$ and the combination at $24 \mathrm{~h}(P=0.51)$ although both of these treatments produced greater decreases in serum tryptophan than IFN- $\beta_{\text {ser }}(P \leq 0.03)$. A significant dose-response effect was seen for both IFN- $\gamma$ and the combination at $24 \mathrm{~h}$, but not for IFN- $\beta_{\text {ser }}(P=0.004,0.005$, and 0.94 , respectively).

Indoleamine 2,3 dioxygenase activity as measured by urinary kynurenine levels. In parallel with the decrease in serum tryptophan levels observed after IFN- $\gamma$ or IFN- $\beta_{\text {ser }} /$ IFN- $\gamma$, there was a reciprocal increase in urinary excretion of kynurenine at $24 \mathrm{~h}$ at both dose levels $(P \leq 0.003)$ (Fig. 5, $C$ and $D)$. IFN- $\gamma$ increased urinary kynurenine levels in 17 of 20 patients, and the combination increased levels in 18 of 20 patients. A significant increase was observed for IFN- $\beta_{\text {ser }}$ at the lower dose levels (six of nine patients) $(P=0.048)$ but not the higher (five of nine patients) $(P=0.38)$. As with serum tryptophan levels, the changes in urinary kynurenine induced by IFN- $\gamma$ and IFN- $\beta_{\text {ser }} / I F N-\gamma$ were not significantly different from one another $(P=0.24)$. IFN- $\beta_{\text {ser }} /$ IFN- $\gamma$, however, induced significantly higher urinary kynurenine levels at $24 \mathrm{~h}$ than did IFN- $\beta_{\text {ser }}(P=0.004)$. A dose response relationship was observed for IFN- $\gamma$ and the combination treatment, but not for IFN- $\beta_{\text {ser }}(P=0.056,0.03$, and 0.67 , respectively).

\section{Effector cell cytotoxicity}

$N K$ and $A D C C$ activity. IFN- $\gamma$ decreased NK cell activity by $32 \%$ when measured $24 \mathrm{~h}$ after treatment $(P=0.026)$ (Fig. 6 

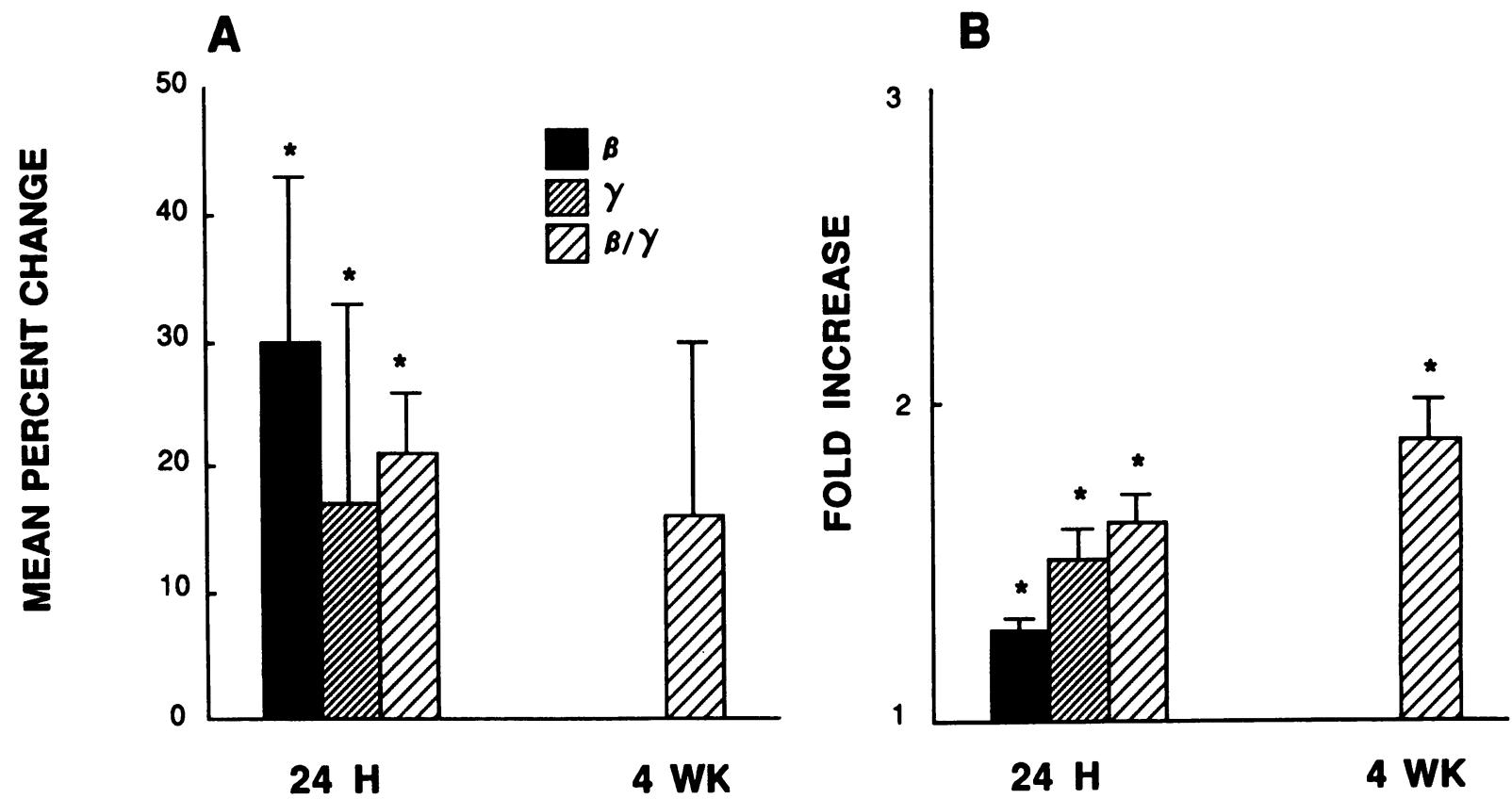

Figure 3. Effects of combined dose levels of IFN- $\beta_{\text {ser }}(\beta)$, IFN- $\gamma(\gamma)$, and IFN- $\beta_{\text {ser }} / \mathrm{IFN}-\gamma(\beta / \gamma)$ on $\beta_{2}$ microglobulin expression on $(A)$ monocytes and $(B)$ serum levels. Results are given as mean percent change (reexpressed from analysis of log-transformed data) of values measured pretreatment compared to those measured $24 \mathrm{~h}$ postinjection, and after $4 \mathrm{wk}$ of maintenance treatment. The MFI on monocytes increased from 113.2 to $140.324 \mathrm{~h}$ after IFN- $\beta_{\text {ser }}$, from 120.9 to 140.0 after IFN- $\gamma$, and from 129.6 to 155.5 after the combination. After 4 wk of maintenance with the combination, the MFI increased from 123.4 to 144.9. Mean serum $\beta_{2}$ microglobulin increased from 2.7 to $3.6 \mathrm{mg} / \mathrm{liter} 24 \mathrm{~h}$ after IFN- $\beta_{\text {ser }}$, from 2.7 to $3.9 \mathrm{mg} /$ liter after IFN- $\gamma$, and from 2.7 to $4.4 \mathrm{mg} /$ liter after the combination. After $4 \mathrm{wk}$ of IFN- $\beta_{\text {ser }} /$ IFN- $\gamma$, mean serum $\beta_{2}$ microglobulin increased from 2.8 to $5.5 \mathrm{mg} /$ liter. Asterisks indicate significant differences compared with baseline $(P<0.05)$. Error bars $=$ SE.

$A$ ). Although IFN- $\beta_{\text {ser }}$ and IFN- $\beta_{\text {ser }} /$ IFN- $\gamma$ also decreased NK activity compared with pretreatment values, these decreases were not statistically significant $(P=0.66$ and 0.29 , respectively). IFN- $\gamma$ did not depress NK cell activity significantly more than IFN- $\beta_{\text {ser }}$ or the combination $(P \geq 0.21)$. ADCC was decreased by both IFN- $\beta_{\text {ser }}(13$ of 20 patients $)(P=0.032)$ and IFN- $\gamma(14$ of 19 patients $)(P=0.004)$, but not IFN- $\beta_{\text {ser }} /$ IFN- $\gamma$ (10 of 18 patients) $(P=0.65)$ (Fig. $6 B$ ). Similar to results observed with NK cell activity, the combination did not de- crease ADCC significantly less than either IFN alone ( $P$ $\geq 0.36$ ). Statistical analysis showed no significant dose response relationship was observed for either NK cell activity or ADCC activity by IFN- $\beta_{\text {ser }}$, IFN- $\gamma$, or the combination $(P \geq$ 0.09).

4 wk of maintenance IFN- $\beta_{\text {ser }} /$ IFN- $\gamma$ did not enhance NK cell activity $(P=0.75)$ (Fig. $6 A)$. ADCC activity, however, was enhanced after 4 wk of the higher dose level $(P=0.021)$ but not the lower $(P=0.54)$ (data not shown). When data from the
A

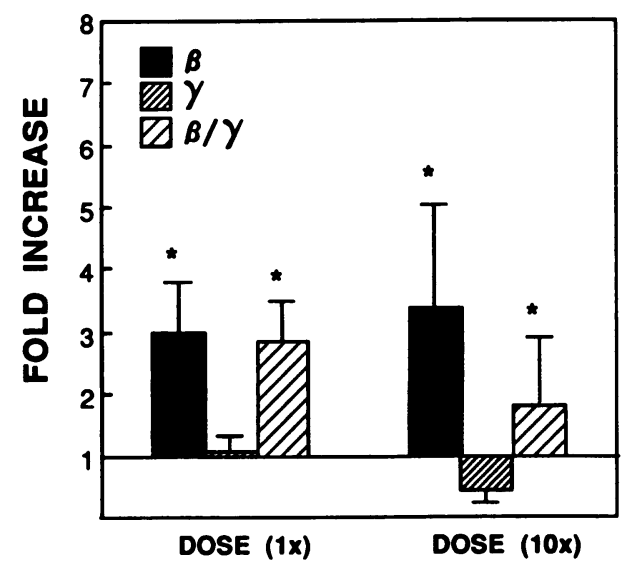

B

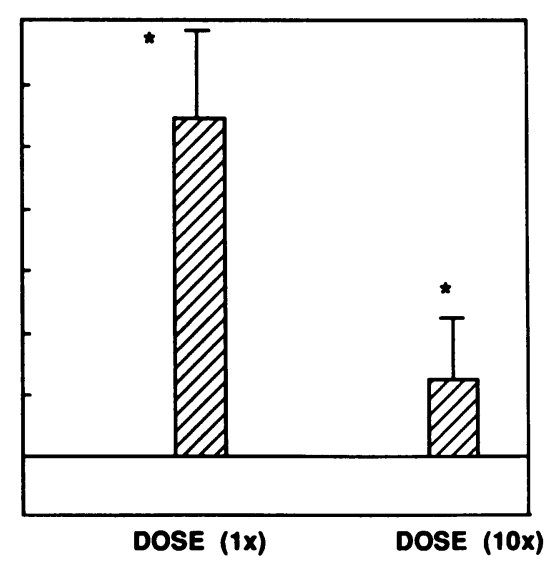

Figure 4. Effects of low dose or higher dose $(10 \times)$ of IFN- $\beta_{\text {ser }}(\beta), \operatorname{IFN}-\gamma(\gamma)$, and IFN- $\beta_{\text {ser }} /$ IFN- $\gamma(\beta / \gamma)$ on $2-5$ A synthetase activity $(A) 24 \mathrm{~h}$ postinjection, and $(B)$ after 4 wk of maintenance treatment. Mean 2-5A synthetase activity increased from $11.3 \mathrm{pmol} / 10^{5}$ cells per $\mathrm{h}$ to 20.1 pmol $/ 10^{5}$ cells per $\mathrm{h} 24 \mathrm{~h}$ after the lower dose of IFN- $\beta_{\text {ser }}$, from 7.7 to $8.2 \mathrm{pmol} / 10^{5}$ cells per $h$ after the lower dose of IFN- $\gamma$, and from 5.3 to $14.1 \mathrm{pmol} / 10^{5}$ cells per $h$ after the lower dose of the combination. 24 $h$ after the high dose of IFN- $\beta_{\text {ser }}$, IFN- $\gamma$, and the combination, mean levels changed from 10.0 to 30.1 , from 16.3 to 17.0 , and from 8.0 to $22.7 \mathrm{pmol} / 10^{5}$ cells per $\mathrm{h}$, respectively. Mean 2-5A synthetase activity increased from 4.7 to $27.9 \mathrm{pmol} / 10^{5}$ cells per $h$ after 4 wk of the lower dose

of the combination, and from 13.7 to $25.9 \mathrm{pmol} / 10^{5}$ cells per $\mathrm{h}$ after the higher dose. Asterisks indicate significant differences compared with baseline $(P<0.05)$. Error bars $=\mathrm{SE}$. 


\section{SERUM TRYPTOPHAN}
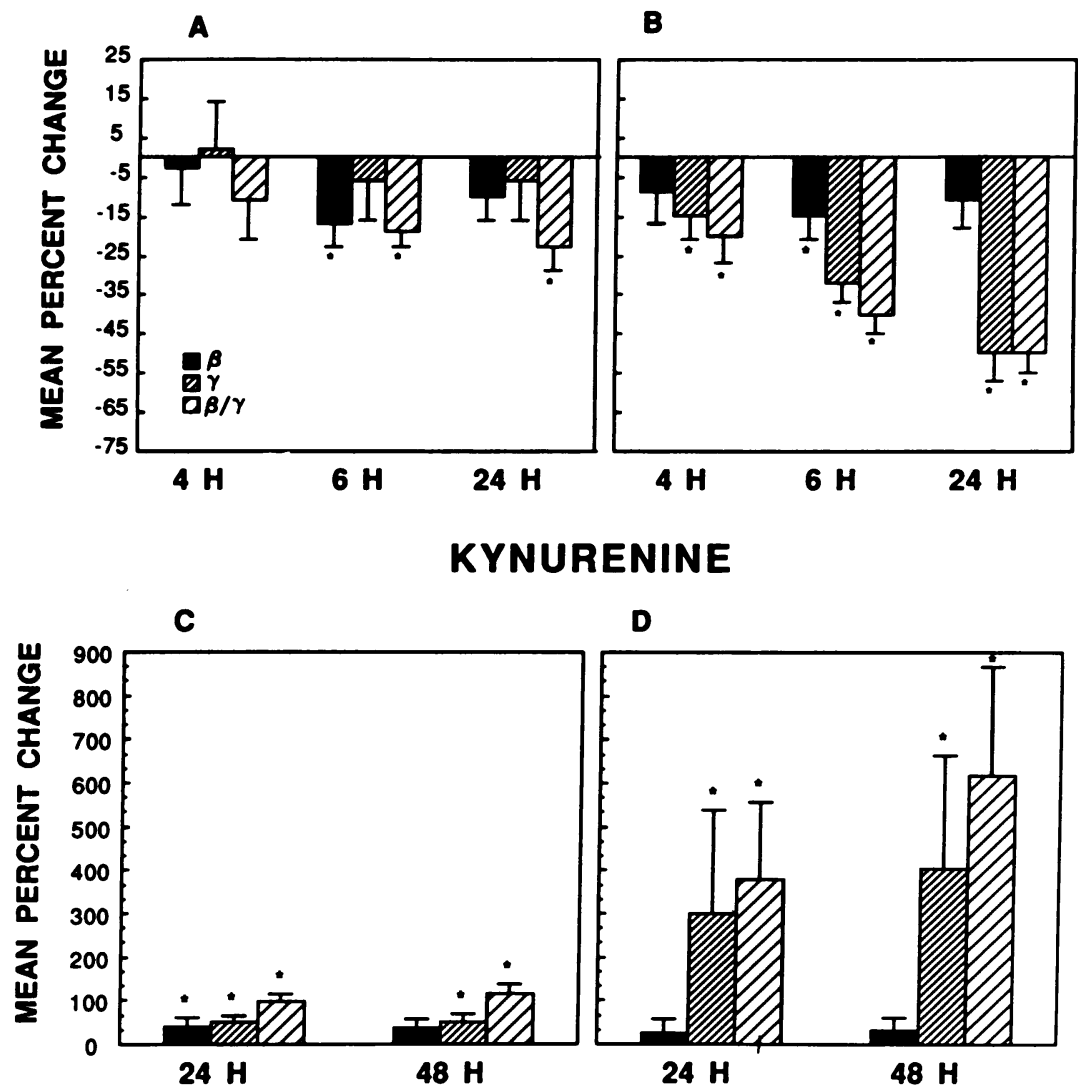

Figure 5. Effects of lower $(1 \times)$ or higher $(10 \times)$ dose of IFN- $\beta_{\text {ser }}(\beta)$, IFN- $\gamma(\gamma)$, and IFN- $\beta_{\text {ser }} / \mathrm{IFN}-\gamma(\beta / \gamma)$ on indoleamine 2,3 dioxygenase activity: $(A$ and $B)$ serum tryptophan levels and ( $C$ and $D$ ) urinary kynurenine levels. Results are given as mean percent change (reexpressed from analysis of log-transformed data) of values measured pretreatment compared to those measured 4,6 , and $24 \mathrm{~h}$ postinjection ( $A$ and $B$ ), and 24 and $48 \mathrm{~h}$ posttreatment $(C$ and $D)$. Mean serum trypotophan levels changed from 1.2 to 1.1 $\mathrm{mg} / \mathrm{dl} 24 \mathrm{~h}$ after the lower dose of IFN- $\beta_{\text {ser }}$, from 1.1 to $1.1 \mathrm{mg} / \mathrm{dl}$ after the lower dose of IFN- $\gamma$, and from 1.2 to $1.0 \mathrm{mg} / \mathrm{dl}$ after the lower dose of the combination. After the higher dose of IFN- $\beta_{\text {ser }}$, IFN- $\gamma$, and the combination, mean serum tryptophan levels decreased from 1.1 to 1.0 , from 1.1 to 0.6 , and from 1.1 to $0.5 \mathrm{mg} / \mathrm{dl}$, respectively. Mean urinary kynurenine concentrations increased from 27.1 to $40.3 \mu \mathrm{mol} / \mathrm{d}$ $24 \mathrm{~h}$ after the lower concentration of IFN- $\beta_{\text {ser }}$, from 26.7 to 36.9 after the lower concentration of IFN- $\gamma$, and from 19.1 to $37.1 \mu \mathrm{mol} / \mathrm{d}$ after the lower concentration of the combination. $24 \mathrm{~h}$ after the administration of the higher concentrations of IFN- $\beta_{\text {ser }}$ IFN- $\gamma$, and the combination, mean urinary kynurenine concentrations increased from 51.0 to 48.9 , from 29.5 to 153.1 , and from 57.0 to $246.4 \mu \mathrm{mol} / \mathrm{d}$, respectively. Asterisks indicate significant differences compared with baseline with $P<0.05$. Error bars $=$ SE.

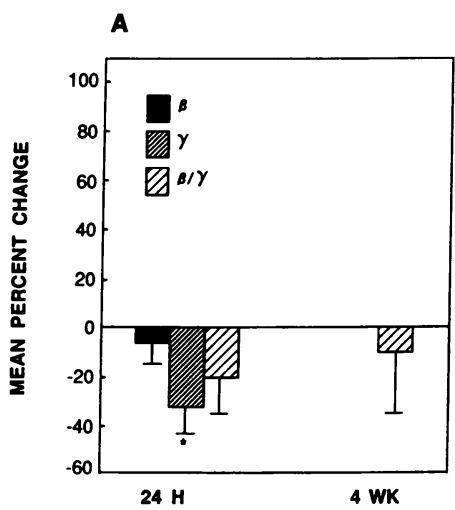

B

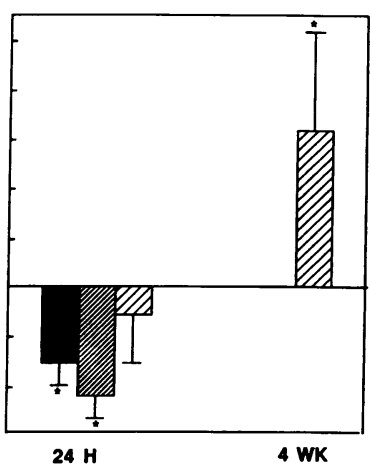

Figure 6. Effects of combined dose levels of IFN $-\beta_{\text {ser }}(\beta), \operatorname{IFN}-\gamma(\gamma)$, and IFN- $\beta_{\text {ser }} /$ IFN- $\gamma(\beta / \gamma)$ on $(A)$ NK cell activity and $(B)$ ADCC activity. Results are given as mean percent change (reexpressed from analysis of log-transformed data) of values measured pretreatment compared with those measured $24 \mathrm{~h}$ postinjection, and after $4 \mathrm{wk}$ of maintenance treatment. Mean NK activity changed from 194.5 lytic units $/ 10^{7}$ cells to 200.9 lytic units $/ 10^{7}$ cells $24 \mathrm{~h}$ after IFN- $\beta_{\text {ser }}$, from 162.4 to 104.1 after IFN- $\gamma$, and from 183.0 to 193.3 lytic units $/ 10^{7}$ cells after the combination. Mean ADCC activity changed from 459.3 lytic units $/ 10^{7}$ cells to 344.0 lytic units $/ 10^{7}$ cells $24 \mathrm{~h}$ after administration of IFN- $\beta_{\text {ser }}$, from 341.1 to 225.6 after IFN- $\gamma$, and from 393.1 to 396.7 after the combination. After $4 \mathrm{wk}$ of maintenance treatment with the combination, mean NK activity and ADCC activity changed from 162.4 to 195.6 lytic units $/ 10^{7}$ cells, and 345.1 to 655.8 lytic units $/ 10^{7}$ cells, respectively. Columns with asterisks show significant differences with $P<0.05$. Error bars $=\mathrm{SE}$. two dose levels were combined (Fig. $6 \mathrm{~B}$ ), ADCC activity was increased $63 \%(P=0.042)$.

Serum neopterin levels. Significant increases in serum neopterin levels were observed after all three IFN treatments at both dose levels (Fig. 7). All three IFN treatments increased serum neopterin in all patients studied. IFN- $\beta_{\text {ser }} /$ IFN- $\gamma$ treatment increased serum neopterin levels by a mean of 3.0 -fold, an augmentation that was significantly higher than the 2.2-fold increase induced by IFN- $\gamma$, but only marginally significantly higher than the 2.5 -fold increase induced by IFN- $\beta_{\text {ser }}(P$ $=0.005$, and 0.06 , respectively). No dose response effect was noted in any of the treatment groups $(P \geq 0.34)$. Serum neopterin levels were not obtained after 4 wk of maintenance treatment with IFN- $\beta_{\text {ser }} /$ IFN- $\gamma$.

\section{Clinical tolerance}

Single injections. Subjective side effects were dose related and qualitatively similar to those typically associated with IFN (Table III). The most common side effects of moderate or greater severity at the lower dose were fatigue and headache. Symptoms of moderate or greater severity were more frequent at the higher dose (Table III). Incidence of anorexia, nausea, and vomiting was slightly greater after the combination, and incidence of fatigue was slightly higher after IFN- $\gamma$. Rigors requiring parenteral meperidine (grade 2 ) were not observed at the lower dose but occurred in three patients at the higher dose (one patient on IFN- $\beta_{\text {ser }}$ and two on IFN- $\beta_{\text {ser }} /$ IFN- $\gamma$ ).

Vital signs including temperature, pulse, respiration and 


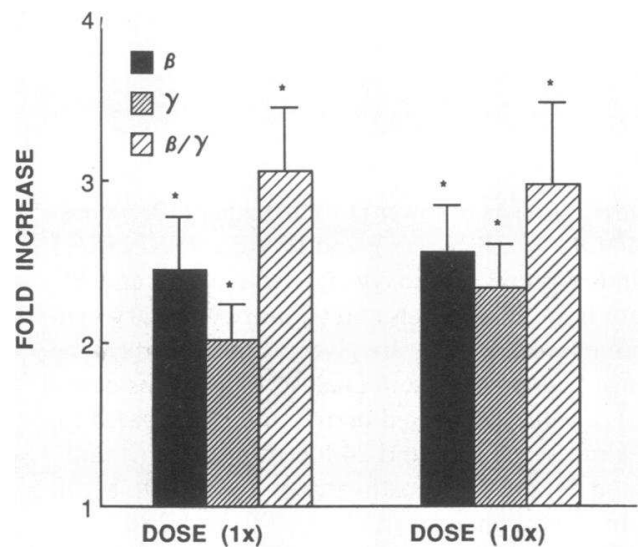

Figure 7. Effects of lower $(1 \times)$ or higher $(10 \times)$ dose on serum neopterin. Results are given as mean percent change (reexpressed from analysis of log-transformed data) of values measured pretreatment compared with those measured $24 \mathrm{~h}$ postinjection, and after $4 \mathrm{wk}$ of maintenance treatment. Mean serum neopterin levels increased from $9.6 \mathrm{nmol} /$ liter to $21.3 \mathrm{nmol} / \mathrm{liter} 24 \mathrm{~h}$ after the lower concentrations of IFN- $\beta_{\mathrm{ser}}$, from 8.2 to $15.5 \mathrm{nmol} /$ liter after the lower concentration of IFN- $\gamma$, and from 9.0 to $25.3 \mathrm{nmol} / \mathrm{liter}$ after the lower concentrations of the combination. $24 \mathrm{~h}$ after administration of the higher concentrations of IFN- $\beta_{\text {ser }}$, IFN- $\gamma$, and the combination, mean serum neopterin levels increased from 13.3 to $31.9 \mathrm{nmol} /$ liter, from 14.4 to $33.2 \mathrm{nmol} /$ liter, and from 12.8 to $35.9 \mathrm{nmol} /$ liter, respectively. Columns with asterisks show significant differences with $P$ $<0.05$. Error bars $=\mathrm{SE}$.

blood pressure were recorded pretreatment and 1, 2, 4, and $6 \mathrm{~h}$ after administration of IFN(s). There were no temperatures $>40^{\circ} \mathrm{C}$. Mean maximum temperatures were equivalent for both dose levels of IFN- $\beta_{\text {ser }}\left(37.9^{\circ} \mathrm{C}\right)$. For the higher dose level of IFN- $\gamma$, mean temperature was higher $\left(38.2^{\circ} \mathrm{C}\right.$, range $36.7-38.4)$ than at the lower $\left(37.5^{\circ} \mathrm{C}\right.$, range $\left.37.0-39.7^{\circ} \mathrm{C}\right)$. The mean maximum temperature at the higher dose was slightly higher for the combination $\left(38.4^{\circ} \mathrm{C}\right)$ than either IFN alone. Acetaminophen (650 mg p.o.) was administered $30 \mathrm{~min}$ before treatment and every $4 \mathrm{~h}$ for a total dose of $2,600 \mathrm{mg}$ with all treatments at the higher dose level.

After 4 wk of maintenance therapy with the combination at the low dose, dose-limiting toxicity was observed in two patients. One patient required dose reduction for grade 3 weight loss (9.4\% of baseline) and another for grade 3 fatigue and a performance status decrease of $\geq 2$ levels. After 4 wk of therapy with the combination, the incidence of moderate or severe fatigue, headache, myalgias, and anorexia decreased (Table III). Four of eight patients at the high dose level had a performance status decrease of $\geq 2$ levels, which was attributed to concomitant disease progression in three of these patients. One patient with severe fatigue, nausea, and vomiting, and grade 4 weight loss ( $10.3 \%$ of baseline) required dose modification.

Transaminase elevation (210 IU/liter serum glutamic oxalo acetic acid transferase (SGOT)) was dose limiting in one patient who was receiving $1 \times 10^{6}$ IU of IFN- $\beta_{\text {ser }}$ with $70 \mu \mathrm{g}$ IFN- $\gamma$ after a dose reduction for fatigue.

\section{Laboratory parameters}

Single injections. Hematologic parameters were measured before and $24 \mathrm{~h}$ after single weekly injections. Significant decreases in neutrophils, platelets, hemoglobin, and white blood counts were observed (Table IV). Although these changes were statistically significant, none were clinically significant. No significant alterations in renal or hepatic function were observed after any of the first injections.

After 4 wk of maintenance therapy with the combination IFN- $\beta_{\text {ser }} /$ IFN- $\gamma$, there were significant decreases in hemoglobin, hematocrit, neutrophils, total white blood cell count, and significant increases in SGOT and lactate dehydrogenase (LDH) when compared with pretreatment values (Table V). The hepatic function changes were not clinically significant, except in one patient who developed an elevated SGOT of 210 IU/liter while receiving $1 \times 10^{6} \mathrm{IU}$ IFN- $\beta_{\text {ser }}$ and $70 \mu \mathrm{g}$ IFN- $\gamma$ after a dose reduction for fatigue. The mean duration on maintenance therapy was $15.5 \mathrm{wk}$ for the dose level $\mathrm{A}$ and $5.9 \mathrm{wk}$ for the dose level B (range: 4-31 wk and 1-13 wk, respectively). No objective responses were seen at either dose level.

\section{IFN pharmacokinetics}

Serum IFN- $\gamma$ and total serum IFN levels were assessed following the administration of IFN- $\beta_{\text {ser }}$, IFN- $\gamma$, or IFN- $\beta_{\text {ser }} / I F N-\gamma$. Because the first sample was collected $15 \mathrm{~min}$ after all IFN had been injected, true "peak" values were not obtained. However, in general, serum IFN levels were dose related. Administration of low doses of IFN- $\gamma(200 \mu \mathrm{g})$ produced maximum IFN- $\gamma$ titers of $35 \mathrm{U} / \mathrm{ml}$, whereas administration of $2,000 \mu \mathrm{g}$ of IFN- $\gamma$ produced mean IFN- $\gamma$ antiviral titers of $150 \mathrm{U} / \mathrm{ml}$. Similarly,

Table III. Differences in Side Effects between IFN Types

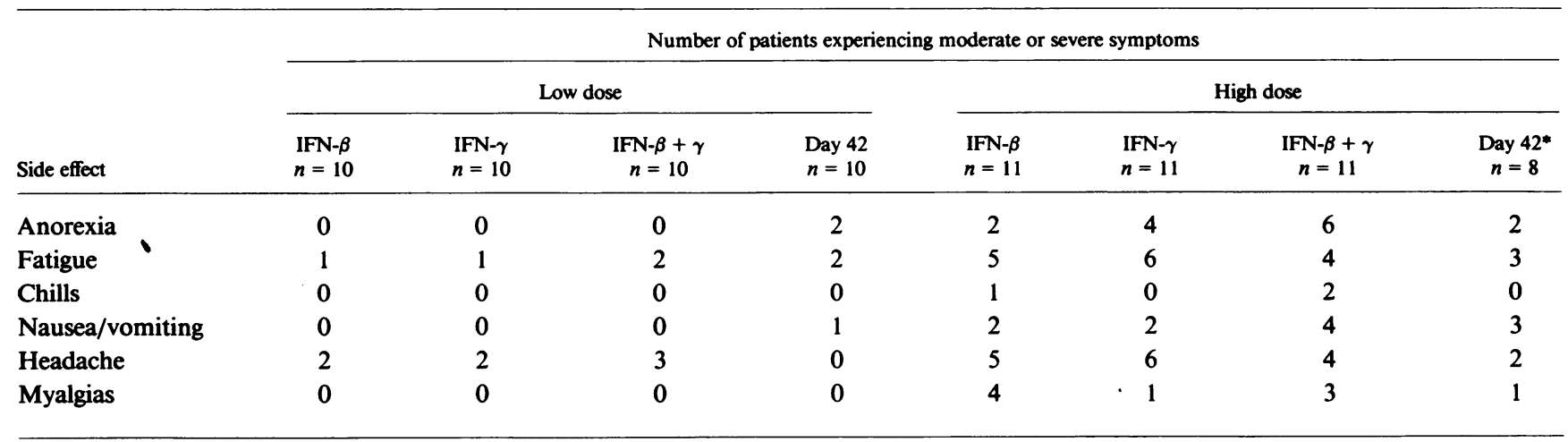

* Three patients withdrew before day 42 . 
Table IV. Hematological Changes 24 after the Administration of IFN- $\beta_{s e r}, I F N-\gamma, I F N-\beta_{s e r} / I F N-\gamma$

\begin{tabular}{|c|c|c|c|c|c|c|}
\hline & \multicolumn{3}{|c|}{ Lower dose } & \multicolumn{3}{|c|}{ Higher dose } \\
\hline & IFN- $\beta_{\text {ser }}$ & IFN- $\gamma$ & $\mathrm{IFN}-\beta_{\text {sec }} / \mathrm{IFN}-\gamma$ & IFN $-\beta_{\text {ser }}$ & IFN- $\gamma$ & IFN $-\beta_{s e f} / I F N-\gamma$ \\
\hline $\begin{array}{l}\text { Hematocrit } \\
\qquad(\mathrm{ml} / \mathrm{dl})\end{array}$ & -0.1 & 0.5 & -0.7 & $-1.5^{*}$ & $-1.8^{*}$ & -0.5 \\
\hline $\begin{array}{l}\text { White blood coun } \\
\left(\times 10^{3} / \mathrm{mm}^{3}\right)\end{array}$ & $-1.8^{*}$ & -1.3 & $-2.6^{*}$ & $-2.8^{*}$ & $-3.1^{*}$ & $-3.0^{*}$ \\
\hline $\begin{array}{l}\text { Neutrophils } \\
\qquad\left(\times 10^{3} / \mathrm{mm}^{3}\right)\end{array}$ & $-1.6^{*}$ & $-1.5^{*}$ & $-3.0^{*}$ & $-1.9^{*}$ & $-2.1^{*}$ & $-2.4^{*}$ \\
\hline $\begin{array}{l}\text { Lymphocytes } \\
\qquad\left(\times 10^{3} / \mathrm{mm}^{3}\right)\end{array}$ & -0.17 & -0.15 & -0.11 & $-0.44^{*}$ & $-0.29^{*}$ & $-0.57^{*}$ \\
\hline $\begin{array}{l}\text { Platelets } \\
\qquad\left(\times 10^{3} / \mathrm{mm}^{3}\right)\end{array}$ & -12.3 & 2.2 & -24.8 & -7.6 & -48.1 & $-43.3^{*}$ \\
\hline
\end{tabular}

${ }^{*} P<0.05$ by paired $t$ test, posttreatment values compared with pretreatment values.

$3 \times 10^{6} \mathrm{U}$ of IFN- $\beta_{\text {ser }}$ or IFN- $\beta_{\text {ser }}$ plus IFN- $\gamma$ produced total IFN titers of $168-254 \mathrm{U} / \mathrm{ml}$, whereas the $30 \times 10^{6} \mathrm{U}$ dose level gave levels of $994-1,342 \mathrm{U} / \mathrm{ml}$. These levels fell rapidly over the next $6 \mathrm{~h}$ to values that were not significantly different from baseline. Considering the large degree of variability associated with serum IFN levels, we were not able to detect a significant alteration in the pharmacokinetics of either total serum IFN levels or IFN- $\gamma$ levels after the administration of combined IFN- $\beta_{\text {ser }} /$ IFN- $\gamma$ when compared to either IFN- $\gamma$ or IFN- $\beta_{\text {ser }}$ alone.

\section{Discussion}

This study, the first to directly compare biological and clinical effects of a type I (IFN- $\alpha$ or IFN- $\beta$ ) and type II (IFN- $\gamma$ ) within the same patient, provided the unique opportunity to directly compare the side effects associated with two different IFN types, as well as to determine any qualitatively or quantitatively differences associated with the combination of IFN- $\beta_{\text {ser }}$ and IFN- $\gamma$. The order of administration of the three treatment groups was distributed equally among patients in each dose level to control for cumulative side effects. Based upon our prior studies $(17,20)$, a 1-wk washout period between treatments allowed for reversal of biological and clinical effects.

Although there were slight differences in constitutional symptoms after the administration of a single dose of IFN- $\beta$, IFN- $\gamma$, or the combination, these were not clinically significant. Although constitutional symptoms or clinical side effects were more pronounced at the higher dose levels of IFN- $\beta$, IFN- $\gamma$, or the combination, these side effects were tolerable. Four weeks of maintenance therapy with the combination of IFN- $\beta$ and IFN- $\gamma$ was tolerated at both dose levels, although more side effects occurred at the higher dose. With the exception of a mild increase in the SGOT at the higher dose, none of the changes in laboratory parameters after $4 \mathrm{wk}$ of IFN- $\beta_{\text {ser }} /$ IFN- $\gamma$ were of clinical importance. Thus, no notable clinical differences in side effects or toxicities between IFN- $\beta_{\text {ser }}$ and IFN- $\gamma$ were observed. Other investigators have reported that the maximally tolerated dose of an IFN- $\alpha$ and IFN- $\gamma$ combination was well below the maximally tolerated dose of either

Table V. Hematologic, Hepatic, and Renal Toxicities after 1 mo of Maintenance IFN- $\beta_{s e r} / I F N-\gamma$

\begin{tabular}{|c|c|c|c|c|c|c|}
\hline & \multicolumn{3}{|c|}{ Lower dose } & \multicolumn{3}{|c|}{ Higher dose } \\
\hline & \multicolumn{2}{|c|}{ Mean values } & \multirow[b]{2}{*}{$P^{*}$} & \multicolumn{2}{|c|}{ Mean values } & \multirow[b]{2}{*}{$P^{*}$} \\
\hline & On study & $\begin{array}{c}\text { After } 1 \text { mo } \\
\text { IFN- } \beta_{\text {ser }} / \mathrm{IFN}-\gamma\end{array}$ & & On study & $\begin{array}{c}\text { After } 1 \mathrm{mo} \\
\text { IFN- } \beta_{\text {sec }} / \mathrm{IFN}-\gamma\end{array}$ & \\
\hline \multicolumn{7}{|l|}{ Hemoglobin } \\
\hline$(g m / d l)$ & 13.0 & 12.0 & 0.036 & 12.1 & 11.5 & 0.05 \\
\hline \multicolumn{7}{|l|}{ Hematocrit } \\
\hline$(m l / d l)$ & 38.8 & 36.0 & 0.032 & 35.2 & 33.6 & 0.10 \\
\hline \multicolumn{7}{|l|}{ White blood count } \\
\hline$\left(\times 10^{3} / \mathrm{mm}^{3}\right)$ & 8.2 & 5.9 & $<0.001$ & 7.1 & 6.6 & 0.74 \\
\hline \multicolumn{7}{|l|}{ Platelets } \\
\hline$\left(\times 10^{3} / \mathrm{mm}^{3}\right)$ & 375 & 370 & 0.90 & 385 & 375 & 0.88 \\
\hline \multicolumn{7}{|l|}{ Creatinine } \\
\hline$(m g / d l)$ & 1.1 & 1.1 & 0.50 & 1.0 & 1.1 & 0.17 \\
\hline SGOT (IU/liter) & 35.7 & 43.8 & 0.08 & 30.0 & 82.0 & 0.026 \\
\hline
\end{tabular}

* By paired $t$ test, Day 42 values compared with baseline values. 
IFN alone; furthermore, patients had persisting fevers and progressive fatigue with the daily intramuscular injections (11). In our study, a higher dose level of IFN- $\beta_{\text {ser }}$ and IFN- $\gamma$ was tolerable when administered for prolonged periods of time, a finding that confirms our previous observations (21). The discrepancies between the combination of IFN- $\alpha$ and IFN- $\beta_{\text {ser }}$ with IFN- $\gamma$ may result from the two different type I IFNs (IFNalfa- $2 \mathrm{a}$ and IFN- $\beta_{\text {ser }}$ ), by differences in the two IFN- $\gamma$ formulations which were used, or by differences in route or schedule of administration.

Quantification of biological response modification by IFNs has been useful to define differences in IFN types, the influence of serum levels, duration of response, and modification of effector cell function in vivo $(2,14,15,17,20)$. Assessment of host responses was undertaken $24 \mathrm{~h}$ after the administration of IFNs, a time identified as yielding modulation in prior studies in vitro and in vivo $(2,14,15,17,20)$. While a kinetic analysis would also be of interest, sample volumes from patients are limited; we thus chose to focus study design on the influence of dose. The biological parameters chosen for study were ones that are known to be modulated by IFNs and may be mediators of antitumor activity.

A synergistic enhancement in biological responses was not observed. With the exception of tryptophan metabolism, the differences were not even additive. The combination of IFN- $\beta_{\text {ser }} /$ IFN- $\gamma$ was more effective than IFN- $\beta$ in enhancing tryptophan metabolism and serum $\beta_{2}$ microglobulin, and more effective than IFN- $\gamma$ in enhancing the expression of 2-5A synthetase and serum neopterin levels. These results are consistent with previous reports that the optimal biological dose was not related to the total dose of IFN $(15,17)$, even when the IFN administered consisted of two IFN types.

One biological response, which was enhanced by IFN- $\beta_{\text {ser }} /$ IFN- $\gamma$ in a dose-dependent but not synergistic fashion was the induction of tryptophan metabolism. Indoleamine 2,3-dioxygenase is an enzyme present in the lung and intestinal mucosa that degrades tryptophan and related indoles to kynurenine and other metabolites (23), and has been found to be induced by viral infections, bacterial lipopolysaccharides, and IFN (23). We have observed tryptophan degradation induced by IFN in vitro and in vivo $(24,25)$. Addition of excess tryptophan to culture media has been able to reverse the antiproliferative effect of IFN- $\gamma$ in several cell lines $(26,27)$.

Neopterin, excreted by human monocytes in response to IFN- $\gamma$, has been used as an assay for monocyte activation (28). In this study, the combination of IFN- $\beta_{\text {ser }} /$ IFN- $\gamma$-enhanced neopterin levels over IFN- $\gamma$ alone. Furthermore, the increase in neopterin levels produced by the combination, when compared to the increase in neopterin produced by IFN- $\beta_{\text {ser }}$ bordered on statistical significance $(P=0.057)$.

We have previously shown that IFN- $\gamma$ and IFN- $\beta$ enhances HLA-DR and HLA-DQ expression on monocytes in cancer patients $(15,29)$; the current study confirms those observations, extends them to the combination of IFN- $\beta_{\text {ser }} /$ IFN- $\gamma$, and determined that IFN- $\gamma$ was no more effective than IFN- $\beta_{\text {ser }}$. This latter result differed from studies of tumor cell lines in vitro $(30,31)$. In contrast, IFN- $\beta$ has been shown to have an antagonistic effect on the IFN- $\gamma$ induced expression of Ia antigen in murine macrophages (32). We found no potentiation of HLA class I or II expression by the combination of IFN- $\beta_{\text {ser }} /$ IFN- $\gamma$ over either IFN- $\beta_{\text {ser }}$ or IFN- $\gamma$.
We observed no enhancement over baseline in NK cell activity with IFN- $\beta_{\text {ser }} / I F N-\gamma$. These results differ from those observed in immune cells in vitro, in which lymphocyte NK cell activity by IFN- $\gamma$ was potentiated by IFN- $\alpha$ or IFN- $\beta_{\text {ser }}$ (33). The lack of NK cell enhancement by IFN- $\beta_{\text {ser }}$ and the decrease in NK cell activity by IFN- $\gamma$ also differ from the potentiation of NK cell activity we and others have consistently observed with IFN- $\alpha$ and IFN- $\beta(17,34,35)$. Other investigators, however, have reported the absence of signifcant NK cell activity and ADCC activity in patients treated with 4-h infusions of IFN- $\gamma(31)$, although this has not been confirmed by other groups using a different IFN- $\gamma$ preparation given intramuscularly (36). In this study, ADCC activity was enhanced after 4 wk of the combination treatment. To determine whether this variability in response results from movement of non-MHC-restricted effector cells from circulation to tumor sites, differences in disease stage or type, or active suppression by the IFNs administered, would require additional quantitative studies.

In summary, when compared with either IFN- $\beta_{\text {ser }}$ or IFN- $\gamma$ alone, the combination of IFN- $\beta_{\text {ser }} /$ IFN- $\gamma$ did result in a significantly greater enhancement of serum $\beta_{2}$ microglobulin compared with that induced by IFN- $\beta_{\text {ser }}$, a significantly greater increase in urinary kynurenine levels compared to IFN- $\beta_{\text {ser }}$, and a significantly greater increase in neopterin levels and $2-5$ A synthetase activity compared with IFN- $\gamma$. Since these changes were not synergistic, we conclude that the combination of IFN- $\beta_{\text {ser }} /$ IFN- $\gamma$ at this dose and schedule did not potentiate host responses more than either IFN alone. Consistent with these findings, doses of IFN- $\beta_{\text {ser }}$ and IFN- $\gamma$ resulted in no significant added host toxicity.

These results contrast with the synergistic antiproliferative effects that have been observed in vitro and in mouse tumor models $(7-10)$. The role of IFN- $\beta_{\text {ser }}$, IFN- $\gamma$, and IFN- $\beta_{\text {ser }} /$ IFN- $\gamma$ in the treatment of cancer has yet to be defined. As a basis for Phase II trials, chronic administration of the combination of IFN- $\beta_{\text {ser }}$ and IFN- $\gamma$ was tolerable. Whether direct effect on tumor cells or indirect effects on host responses accounts for antitumor activity of IFNs remains an open question. If Phase II clinical trials using combinations of IFNs show potentiated therapeutic activity, results from this study would support the hypothesis that direct anti-proliferative effects predominate.

\section{Acknowledgments}

We would like to thank Diane Helgesen and Yoshi Fujimiya for their expert technical assistance, Karen Sielaff for help in the coordination of this trial, Liz Schiferl for her aid in data analysis, and Mary Pankratz for her assistance in typing of this manuscript.

This work was supported in part by National Institutes of Health and National Cancer Institute grant N01-CM47669 and Triton Biosciences. J. H. Schiller is a recipient of an American Cancer Society Clinical Oncology Career Development Award. D. M. Paulnock is a Shaw Scholar of the Milwaukee Foundation. E. C. Borden is an American Cancer Society Professor of Clinical Oncology.

\section{References}

1. Borden, E. C., T. F. Hogan, and J. G. Voelkel. 1982. The comparative antiproliferative activity in vitro of natural interferons $\alpha$ and $\beta$ for diploid and transformed human cells. Cancer Res. 42:4948-4953.

2. Nathan, C. F., C. R. Horowitz, J. de la Harpe, S. Vadhan-Raj, S. A. Sherwin, H. F. Oettgen, and S. E. Krown. 1985. Administration 
of recombinant interferon $\gamma$ to cancer patients enhances monocyte secretion of hydrogen peroxide. Proc. Natl. Acad. Sci. USA. 82:86868690.

3. Sidman, C. L., J. D. Marshall, L. D. Shultz, P. W. Gray, and H. M. Johnson. 1984. Gamma-interferon is one of several direct B cell-maturing lymphokines. Nature (Lond.). 309:801-804.

4. Guyre, P. M., P. M. Morganelli, and R. Miller. 1983. Recombinant immune interferon increases immunoglobulin G Fc Receptors on cultured human mononuclear phagocytes. J. Clin. Invest. 72:393-397.

5. Basham, T. Y., and T. C. Merigan. 1983. Recombinant interferon- $\gamma$ increases HLA-DR synthesis and expression. J. Immunol. 130:1492-1494.

6. Schiller, J. H., and E. C. Borden. 1988. Antiproliferative and clinical antitumor effects of interferons. In Leukolysins and Cancer. J. H. Ransom and J. Ortaldo, J., editors. Humana Press, Clifton, NJ. 273-301.

7. Schiller, J. H., D. S. Groveman, S. M. Schmid, J. K. V. Willson, K. B. Cummings, and E. C. Borden. 1986. Synergistic antiproliferative effects of human recombinant $\alpha 54$ or $\beta_{\text {ser }}$ with $\gamma$-interferon on human cell lines of various histogenesis. Cancer Res. 46:483-488.

8. Schiller, J. H., J. K. V. Willson, G. Bittner, W. H. Wolberg, M. J. Hawkins, and E. C. Borden. 1986. Antiproliferative effects of interferons on human melanoma cells in the human tumor colony-forming assay. J. Interferon Res. 6:615-625.

9. Czarniecki, C. W., C. W. Fennie, D. B. Powers, and D. A. Estell. 1984. Synergistic antiviral and antiproliferative activities of Escherichia coli-derived human alpha, beta, and gamma interferons. $J$. Virol. 49:490-496.

10. Schiller, J. H., B. Storer, J. K. V. Willson, and E. C. Borden. 1987. Phase I trial of combinations of recombinant interferons $\beta_{\text {ser }}$ and $\gamma$ in patients with advanced malignancy. Cancer Treat. Rep. 71:945952.

11. Kurzrock, R., M. G. Rosenblum, J. R. Quesada, S. A. Sherwin, L. M. Itri, and J. U. Gutterman. 1986. Phase I study of a combination of recombinant interferon-alpha and recombinant interferon-gamma in cancer patients. J. Clin. Oncol. 4:1677-1683.

12. van der Burg, M., M. Edelstein, L. Gerlis, C-M. Liang, M. Hirschi, and A. Dawson. 1985. Recombinant interferon- $\gamma$ (immuneron): results of a phase I trial in patients with cancer. J. Biol. Response Mod. 4:264-272.

13. Hawkins, M., S. Horning, M. Konrad, S. Anderson, K. Sielaff, S. Rosno, J. Schiesel, T. Davis, D. DeMets, T. Merigan, and E. C. Borden. 1985. Phase I evaluation of a synthetic mutant of $\beta$-interferon. Cancer Res. 45:5914-5920, 1985.

14. Merritt, J. A., E. C. Borden, and L. A. Ball. 1985. Measurement of $2^{\prime}, 5^{\prime}$-oligo-adenylate synthetase in patients receiving interferonalpha. J. Interferon Res. 5:191-198.

15. Paulnock, D. M., K. A. Havlin, B. E. Storer, G. T. Spear, K. M. Sielaff, and E. C. Borden. 1989. Induced proteins in human peripheral mononuclear cells over a range of clinically tolerable doses of interferon gamma. J. Interferon Res. 9:457-473, 1989.

16. Gonwa, T. A., J. P. Frost, and R. W. Karr. 1986. All human monocytes have the capability of expressing HLA-DQ and HLA-DP molecules upon stimulation with interferon- $\gamma$. J. Immunol. 137:519524.

17. Edwards, B. S., M. J. Hawkins, and E. C. Borden. 1984. Comparative in vivo and in vitro activation of human natural killer cells by two recombinant $\alpha$-interferons differing in antiviral activity. Cancer Res. 44:3135-3139.

18. Arend, R. A., J. E. Leklem, and R. R. Brown. 1970. Direct and steam distillation autoanalyzer methods for assay of diazotizable aromatic amine metabolites of tryptophan in urine and in serum. Biochem. Med. 4:457-468.
19. Denckla, W. D., and H. K. Dewey. 1966. The determination of tryptophan in plasma, liver and urine. J. Lab. Clin. Med. 69:160-169.

20. Hawkins, M. J., E. C. Borden, J. A. Merritt, B. S. Edwards, L. A. Ball, E. Grossbard, and K. J. Simon. Comparison of the biologic effects of two recombinant human interferons alpha (rA and $\mathrm{rD}$ ) in humans. J. Clin. Oncol. 2(3):221-226.

21 and 22. Deleted in press.

23. Yasui, H., K. Takai, R. Yoshida, and O. Hayaishi. 1986. Interferon enhances tryptophan metabolism by inducing pulmonary indoleamine 2,3-dioxygenase: its possible occurrence in cancer patients. Proc. Natl. Acad. Sci. USA. 83:6622-6626.

24. Byrne, G. I., L. K. Lehmann, J. G. Kirschbaum, E. C. Borden, C. M. Lee, and R. R. Brown. 1986. Induction of tryptophan degradation in vitro and in vivo: a $\gamma$-interferon-stimulated activity. $J$. Interferon Res. 6:389-396.

25. Carlin, J. M., E. C. Borden, P. M. Sondel, and G. I. Byrne. 1987. Biological response modifier-induced indoleamine 2,3-dioxygenase activity in human peripheral blood mononuclear cell cultures. J. Immunol. 139:2414-2418.

26. de la Maza, L. M., and E. M. Peterson. 1988. Dependence of the in vitro anti-proliferative activity of recombinant human $\gamma$-interferon on the concentration of tryptophan in culture media. Cancer Res. 48:346-350.

27. Ozaki, Y., M. P. Edelstein, and D. S. Duch. 1988. Induction of indoleamine 2,3-dioxygenase: a mechanism of the antitumor activity of interferon-gamma. Proc. Natl. Acad. Sci. USA. 85:1242-1246.

28. Huber, C., J. R. Batchelor, D. Fuchs, A. Hansen, A. Lang, D. Niederwieser, G. Reibnegger, P. Swetly, J. Troppmair, and H. Wachter. 1984. Immune response-associated production of neopterin: release from macrophages primarily under control of interferongamma. J. Exp. Med. 160:310-316.

29. Spear, G. T., D. M. Paulnock, R. L. Jordan, D. M. Meltzer, J. A. Merritt, and E. C. Borden. 1987. Enhancement of monocyte class I and II histocompatibility antigen expression in man by in vivo interferon $\beta$. Clin. Exp. Immunol. 69:107-115.

30. Dolei, A., M. R. Capobianchi, and F. Ameglio. 1983. Human interferon-gamma enhances the expression of class I and class II major histocompatibility complex products in neoplastic cells more effectively than interferon-alpha and interferon-beta. Infect. Immun. 40:172-176.

31. Nickoloff, B. J., T. Y. Basham, T. C. Merigan, and V. B. Morhenn. 1985. Immunomodulatory and antiproliferative effect of recombinant alpha, beta, and gamma interferons on cultured human malignant squamous cell lines, SCL-1, and SW-1271. J. Invest. Dermatol. 84:487-490.

32. Ling, P. D., M. K. Warren, and S. N. Vogel. 1985. Antagonist effect of interferon- $\beta$ on the interferon- $\gamma$-induced expression of Ia antigen in murine macrophages. J. Immunol. 135:1857-1863.

33. Weigent, D. A., M. P. Langford, W. R. Fleischmann, Jr., and G. J. Stanton. 1983. Potentiation of lymphocyte natural killing by mixtures of alpha or beta interferon with recombinant gamma interferon. Infect. Immun. 40:35-38.

34. Neefe, J. R., J. E. Sullivan, M. Ayoob, E. Phillips, and F. P. Smith. 1985. Augmented immunity in cancer patients treated with $\alpha$-interferon. Cancer Res. 45:874-878.

35. Hawkins, M. J., S. E. Krown, E. C. Borden, M. Krimm, F. X. Real, B. S. Edwards, S. A. Anderson, S. Cunningham-Rundles, and H. F. Oettgen. 1984. American Cancer Society Phase I trial of naturally produced interferon beta. Cancer Res. 44:5934-5938.

36. Kurzrock, R., J. Quesada, M. Talpaz, E. M. Hersh, J. M. Reuben, S. A. Sherwin, and J. U. Gutterman. 1986. Phase I study of multiple dose intramuscularly administered recombinant gamma interferon. J. Clin. Oncol. 4:1101-1109. 